\title{
REFERENCES
}

1. Evans CH, Bowen ER, Bowen J, Tew WP, Westcott VC. Synovial fluid analysis by ferrography. J Biochem Biophys Methods 1980;2:11-15.

2. Evans $\mathbf{C H}$, Mears DC, McKnight JL. A preliminary ferrograplic study of the wear particles in buman synovial fluid. Arthritis Rheum (in press).

3. Evans $\mathrm{CH}$, Mears DC, Cosgrove JL. Secretion of neutral proteolytic enzymes by macrophages and synovial cells in response to wear particles in vitro. Trans Orthop Res Soc 1980;5:62

4. Chrisman OD, Fessel JM, Southwick WD. Experimental production of synovitis and marginal articular exostoses in the knee joints of dogs. Yale J Biol Med 1965;37:409-12.

5. Evans $\mathrm{CH}$, Georgescu HI, Mazzocchi RA. Does cellular ageing of chondrocytes engender primary osteoarthritis? Trans Orthop Res Soc (in press).

\section{Regulation of articular cell metabolism by CTAP mediators}

\author{
By C. William Castor, Terrence D. Fremuth, Dedra J. Roberts, M. Charlene Bignall, and Paul A. \\ Hossler; University of Michigan. Arthritis Unit, Ann Arbor, Michigan
}

$\mathbf{S}^{\mathrm{T}}$ UDY of human osteoarthritic chondrocytes in cell culture provides an opportunity to examine factors affecting qualitative and quantitative aspects of proteoglycan synthesis. We have been interested in characteristics and actions of autacoid mediators and drugs capable of regulating proteoglycan synthesis in vitro. Basic ideas arising in the course of this work are shown in Fig. 1. "Connective tissue activation" results from the actions of autacoid mediators, derived in large part from leucocytes or platelets, which induce increased metabolic activity (activation) in connective tissue cells. The activating substances are peptides, which we have termed "connective tissue activating peptides" or CTAP. They have been found in lymphocytes, ${ }^{1}$ tumor cells, platelets, ${ }^{2-4}$ and polymorphonuclear leucocytes. ${ }^{5}$ CTAP-I, -II, and -III have been purified to homogeneity and their amino acid composition is known. CTAP-III, from platelets, has been studied further; its sequence is now known and an RIA is available. CTAP- $P_{2}$, is a second plateletderived mediator recently identified in outdated human platelets. ${ }^{6}$

Dose-response curves testing CTAP-I and CTAPIII against human synovial cell strains show essentially linear dose-response kinetics (Fig. 2). Incremental isotopic incorporation was shown by enzymatic techniques to be almost entirely hyaluronic acid when synovial cell strains were target cultures. When ${ }^{14} \mathrm{C}$ glucosamine was used as a precursor for GAG synthesis in two osteoarthritic human chondrocyte straings, CTAP-I, CTAP-III, and CTAP- $P_{2}$ all caused substantial increments in ${ }^{14} \mathrm{C}$-GAG formation. Addition of a $\beta$-xyloside had little apparent effect on incorporation of glucosamine except when added in the presence of cycloheximide. Cycloheximide markedly reduced the incorporation of glucosamine into GAG, presumably due to inhibiting synthesis of the protein core. Inhibition of GAG synthesis was reversed when $\beta$-xyloside was added. Cortisol caused approximately $50 \%$ inhibition in glucosamine incorporation in basal cultures as well as a marked reduction in the stimulatory effects brought about by the mediators.

Stimulation by CTAP mediators and $\beta$-xyloside can be identified (Table 1) by using ${ }^{35} 50_{4}^{-}$as a precursor. Indomethacin modestly reduced stimulated incorporation of sulfate into sulfated GAG. The combined effects of CTAP mediators and $\beta$-xyloside were somewhat greater than would be expected if they were merely additive.

The ${ }^{14} \mathrm{C}$-glucosamine and sulfate-labeled GAG from chondrocyte cultures were chromatographed over Sephacryl S-300 columns, and a large void volume peak was shown by enzymatic analysis to be largely hyaluronic acid with a small amount of chondroitin $4 / 6$ sulfate (CS-4/6). When the cultures included a $\beta$-xyloside, the void volume component was markedly reduced and a substantial peak developed in the retarded volume. The large peak in the internal volume was shown enzymatically to be primarily CS-

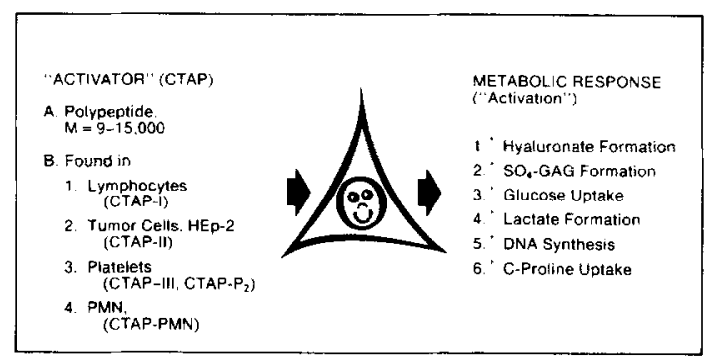

Fig. 1. Connective tissue "activation."

Supported in part by USPHS Grant AM-10728.

(1) 198I by Grune \& Stratton. Inc.

0049-0172/81/1005-0047\$01.00/0 
Table 1. Effects of Mediators and Drugs on ${ }^{36} \mathrm{SO}_{4}$-GAG Synthesis in Human Osteoarthritic Chondrocyte Cultures

\begin{tabular}{|c|c|c|}
\hline Additives & $\begin{array}{c}{ }^{35} \mathrm{SO}_{4}-\mathrm{GAG} \\
\mathrm{CPM} / 20,000 \text { Cells* }\end{array}$ & 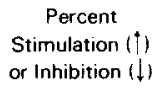 \\
\hline $0.15 \mathrm{M} \mathrm{NaCl}$ & $14,014 \pm 1,016$ & - \\
\hline $0.15 \mathrm{M} \mathrm{NaCl}+10^{-3} \mathrm{MDTF}$ & $14,824+1,575$ & - \\
\hline CTAP-I $(10.6 \mu \mathrm{g} / \mathrm{ml})$ & $20.240 \pm 1,940$ & $37 \% \uparrow$ \\
\hline CTAP-III $(10.1 \mu \mathrm{g} / \mathrm{ml})$ & $28,600 \pm 6,670$ & $104 \% \uparrow$ \\
\hline CTAP-P $_{2}(82 \mu \mathrm{g} / \mathrm{ml})$ & $29,198 \pm 5,276$ & $109 \% \uparrow$ \\
\hline Poly I:Poly C $(50 \mu \mathrm{g} / \mathrm{ml})$ & $17,450 \pm 4,589$ & $25 \% \uparrow$ \\
\hline Insulin $(10 \mu \mathrm{g} / \mathrm{ml})$ & $14,428 \pm 1,417$ & $3 \% \uparrow$ \\
\hline$\beta$-Xyloside $(100 \mu \mathrm{g} / \mathrm{ml})$ & $43,921 \pm 3.036$ & $213 \% \uparrow$ \\
\hline CTAP-I $+\beta$-Xyloside & $58,432 \pm 2,534$ & $294 \% \uparrow$ \\
\hline CTAP-III $+\beta$-Xyloside & $84.889 \pm 3.551$ & $506 \% \uparrow$ \\
\hline CTAP-P ${ }_{2}+\beta$-Xyloside & $82,056 \pm 7,005$ & $486 \% \uparrow$ \\
\hline Insulin $+\beta$-Xyloside & $53,055 \pm 5,663$ & $279 \% \uparrow$ \\
\hline Indomethacin $(15 \mu \mathrm{g} / \mathrm{ml})$ & $14,476 \pm 854$ & $3 \% \uparrow$ \\
\hline CTAP-I + Indocin & $17,248 \pm 1,896$ & $16 \% \uparrow$ \\
\hline CTAP-III + Indocin & $21,190 \pm 1,188$ & $51 \% \uparrow$ \\
\hline CTAP-P $2+$ Indocin & $23,998 \pm 2,873$ & $71 \% !$ \\
\hline
\end{tabular}

"Chondrocyte cell strain was EB-C, 9th passage.

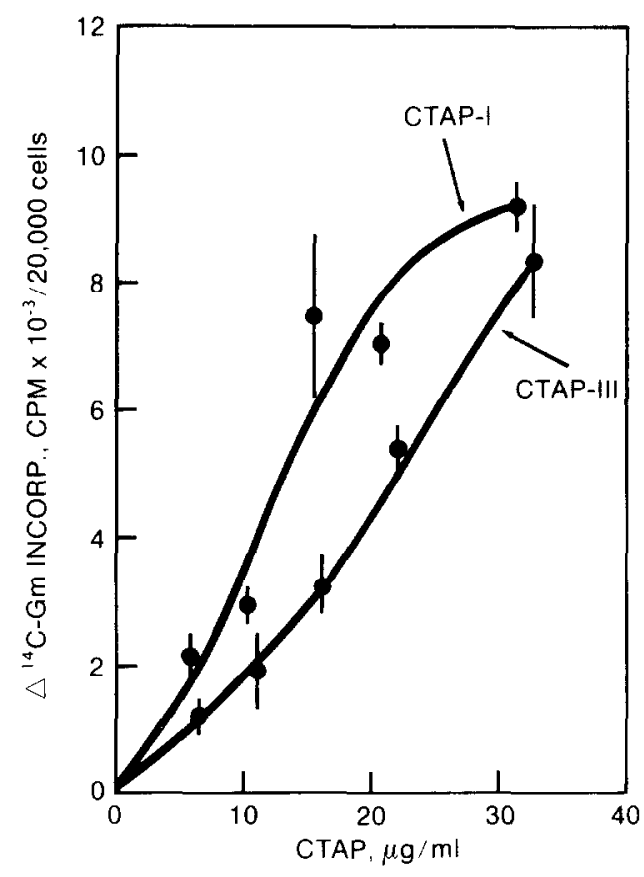

Fig. 2. Dose-response curve.

4/6. Sulfate-labeled GAG showed, in the absence of $\beta$-xyloside, a small peak of radiolabeled material of large molecular weight appearing in the void volume, which was essentially CS-4/6. With $\beta$-xyloside in the incubation mixture, a striking increase in labeled product occurred, which was the lower molecular weight CS-4/6 expected in the internal volume of the column.

The composition of ${ }^{14} \mathrm{C}-\mathrm{GAG}$ synthesized by human chondrocytes in the presence of various test materials was examined, and it was noted that cortisol, indomethacin, and acetylsalicylic acid in clinically relevant concentrations had somewhat different effects on the qualitative composition of these glycosaminoglycans. Cortisol and indomethacin appeared to have a disproportionately greater effect in reducing hyaluronic acid formation, whereas this selective effect appeared less marked with aspirin. It is interesting to note that CTAP-I, -III and $-P_{2}$, all of which cause quantitative increase in GAG synthesis. appeared to retain the relative proportions of GAG seen in control cultures.

In summary, we believe that the quantitative aspects of proteoglycan synthesis are potentially easily subject to modulation by stimulatory and inhibitory factors in the microenvironment of the chondrocytes, and would anticipate that further work will show that the qualitative characteristics relating to the chemical anatomy of proteoglycan aggregates will in a similar manner be subject to modification at the time of synthesis.

\section{REFERENCES}

1. Castor $\mathrm{CW}$. Synovial cell activation induced by a polypeptide mediator. Ann NY Acad Sci 1975;356:304-17.

2. Castor CW, Ritchie JC, Scott ME, Whitney SL. Connective tissue activation: XI. Stimulation of glycosaminoglycan and DNA formation by a platelet factor. Arthritis Rheum 1977;20:859-68.

3. Castor $\mathrm{CW}$, Ritchie JC, William $\mathrm{CH} \mathrm{Jr}$, et al. Connective tissue activation: XIV. Composition and actions of a human platelet autacoid mediator. Arthritis Rheum 1979;22:260-72.

4. Walz DA, Castor CW. Connective tissue activation: Structural studies on a human platelet mitogen. Clin Res 1979;27:649.

5. Myers SL, Castor CW. Connective tissue activation. $X V$. Stimulation of glycosaminoglycan and DNA synthesis by a polymorphonuclear leukocyte factor. Arthritis Rheum 1980;23:556-63.

6. Castor CW, Cobel-Geard SR. Connective tissue activation: Evidence for a second human platelet growth factor. Clin Res 1980;28:139A 